\title{
Female Statues in Ancient Greece and Rome
}

\author{
Rui Deng \\ Department of Arts, Culture and Media, University of Toronto Scarborough Campus, Scarborough M1C \\ 1A4, Canada. \\ rui.deng@mail.utoronto.ca
}

Keywords: Female Statues, Ancient, Art.

\begin{abstract}
This essay focuses on the research about female statues in ancient Greek and Roman art, and also attempts to analysis the development of female statues with their historical contexts. It uses four artworks that came from ancient Greece and Rome to indicate the development of female statues in this time period. With the research about ancient Greco-Roman societies, the essay is trying to build a connection between the changes of social contexts and the development of female statues in ancient Greece and Rome.
\end{abstract}

\section{Introduction}

In human history, the earliest art could be dated back to prehistorical period when people could not even talk. Since there was no language invented, these so called 'art' became a way for people to record events and communicate with others. As the art worked as communication tool in this period, the forms and materials were simple and limited, for instance, the earliest existing cave painting in Chauvet Cave in France. As the time pass by, the art developed into different styles with rules and forms, especially the came out of Academy in Renaissance period defined a new era of artworld. In this period, artworks had certain criterion, and artists were mostly educated in academies about the skill, not only artistic but also reading and writing skills. With these knowledge, artists could create more "perfect" artworks, for example, the David created by Michelangelo could be regarded as a model in Renaissance and Baroque period of perfect human body. Nowadays, art becomes more complicated. Comparing to classical period, modern and contemporary art is not limited by the forms and materials. There are many new things created in contemporary art such as performing art. Without limitation of these physical conditions, artists and audience pay more attention on the ideas that contained in artworks.

Ancient Greco-Roman artworks, as the model of Classical period, played an important role in western art history. This period marked the change of art from recording to expressing. Among those ancient Greco-Roman artworks, female statues affected a lot on the developing of human statues in the future.

Ancient Greek and Rome are commonly known as the origin of western culture. The society, political system, and culture had huge effects on later development of European countries. In ancient Greece, the political system was democracy and people could elect the leader by themselves. However, the election limited to citizens. The term “citizen” in ancient Greek culture specifically means the adult Greek male, which also indicated the social class in ancient Greece. As citizens, or adult male, took the power over the society, the hierarchy of female was very low. The male dominance in society influenced the development of art in ancient Greece, which led to the larger number of male statues compared to female statues.

In ancient Greco-Roman culture, myths took a huge part and affected on other aspects of the

worship of these gods and goddess, the statues of them were in idealized body shape and proportion. These idealized body became a criterion of human body in later years of sculptures, and many sculptors took these statues as examples for their works. 


\section{Method}

\subsection{Kore of Nikandre.}

Ancient Greece and Rome lasted from 12th century BC to the end of antiquity, which was around 7th century AD. During this long period, the society of ancient Greece and Rome developed from small polis to republic and empire. As the society developed, there were many changes happened. From the divide of social class to the development of culture, all of these changes left huge impact on the later time period.

The development of society and culture reflected on female statues a lot in this time period. The subject matter, firstly, changed from divine to mortals, from rulers to ordinary female. Besides, the style of these female statues changed a lot since attitudes of artists and viewers about female body were changed as the time pass by. Developed from stylistic to more natural and realistic form of female statue, reflected a part of the development of cognition of female body. Nevertheless, the change of social structure affected the function of female statues in ancient Greece and Rome.

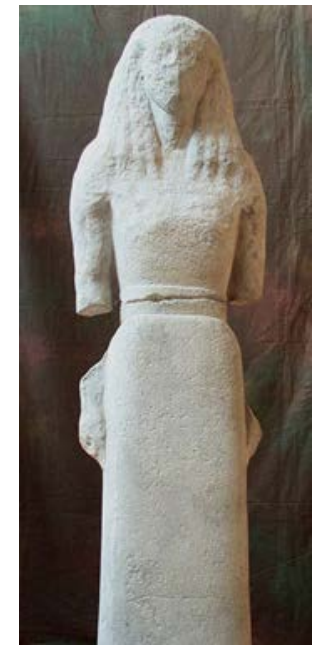

Figure 1 Kore of Nikandre.

Digital image. Museum of Classical Archaeology Databases. Accessed May 22, 2017. http://museum.classics.cam.ac.uk/collections/casts/kore-nikandre.

Kore of Nikandre was an ancient Greek female statues that created in 650-625 BCE. This statue was made by stone; and the size of this statue is 1.75-meter height. According to Mark D. Stansbury-O'Donnell [3], this kore is “one of the earliest in a series of female stone statues.”. Due to the long history and the lack of preservation, the surface of this statue was smashed into flat. In this case, the facial features were vogue which viewers could only recognize the position of eyes and mouths. Her hair is bound into braid. She is wearing a chiton with long sleeves, and there were no decorations on his dress except the belt at waist.

This is a standing figure, and the lines of this statue are straight and smooth. The color of this statue is the original color of the material, and there is no trace of paints on it. The proportion of this statue is awkward. This kore had very slim body shape. Her leg, according to the position of the belt and the foot, was longer than normal proportion, and her head was smaller than normal.

The inscription on this statue: "Nikandre dedicated me to the far-shooter of arrows Artemis, the excellent daughter of Deinodikes of Naxos, sister of Deinomenes, now wife of Phraxos." (Stansbury-O'Donnell, p113) [3] This inscription is so important for two reasons. Firstly, it identified Nikandre as the wife of Phraxos, which shows the importance of marriage of women in ancient Greece. In Status in Classical Athens, author Deborah Kamen states that if a woman in lowclass got married with a man in high-class, her social status would also be improved. Secondly, this inscription indicates that this kore was made as a votive offering that dedicated to Greek goddess Artemis. According to The Female Portrait Statue in the Greek World [2], which written by Sheila Dillon2: "when women were honored by the demos, they were more likely to be honored for their role in important local cults.” (Dillon, 38) Dillon also mentioned that female's characters in 
religious ritual could be seen as a "pendant" of male's civic duties [2]. Under this kind of sexual inequivalence and the restriction of female, this kind of kore which made as votive offerings was the most usual type of female statues in 7th century BCE.

In ancient Greece, the social activity sphere of female was limited in their home, which means that female could not participate into public activities or showed up in public places. But in the worship ritual, it became a special place where only women were allowed to be a priestess. The kore of Nikandre reflected this social circumstance. At this time period, male statues took large part in ancient Greek art. The masculinity dominated not only the politics, social activities, but also in artworld in ancient Greece.

\subsection{Aphrodite at Knidos.}

Besides of the social structure and sexual inequivalence, the culture influenced a lot on the subject matter of female statues in ancient Greece and Rome.

Aphrodite at Knidos, the work of Praxiteles of Athens, was made in 350 BCE. This sculpture is made by marble and the artist, Praxiteles, perfectly shows the feature of marble in curving this Aphrodite.

The facial expression and body are soft and peaceful. The use of white marble shows the divinity and purity of the goddess of love. Her facial features are clearly curved with smooth surface. Praxiteles also uses S-curve shape to show an ideal female bodyline. Her left hand is holding a piece of clothes which suggests her act of bathing.

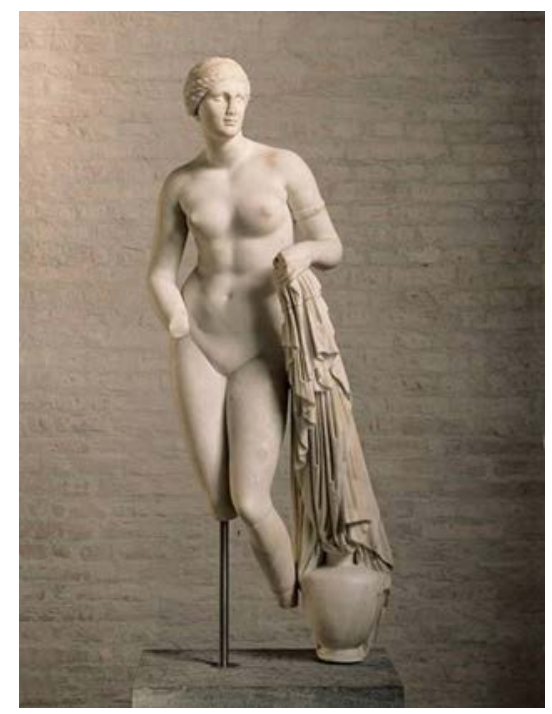

Figure 2 Aphrodite of Knidos of Praxiteles

Digital image. Antikensammlungen und Glyptothek. http://www.antike-am-koenigsplatz.mwn.de /en/glyptothek-munich/collectiontour/classical-greece.html.

As one of the representation of ideal Classical Period female statue, it became a model of female statues in the following period, such as Hellenistic Period and Roman imperial period.

According to Stansbury-O'Donnell [3], there were two versions of this sculpture, one was clothed and another was nude. It was said that Praxiteles was commissioned to make a cult statue of goddess of love by Kos. He made two versions of Aphrodite and sent them to Kos. However, people in Kos rejected the nude one. Although nude male statues were common in the late Classical Period in Greece, female nudity still could not be accepted by Greek public.

In Art, Desire, and the Body in Ancient Greece, the author Andrew Stewart states,[4] "As remarked previously, a strong tradition saw them (women) as inferior males.” (Stewart, p11) Ancient Greek sculptors curved nude male statues to show masculine and power of ideal male. Ancient Greek people worshiped the power of male can be seen in many places. Generals who leaded his army and won the battle always be regarded as hero of his country, such as Heracles and Achilles in Greek mythologies. Athletes who won the champion of Olympic games were also honored by Greek people. Ancient Greek people thought these males become heroes because of 
their power. Under this situation, Greek sculptors curved apparent muscles on male sculptures without coverings to show their power and imply that they are heroes.

However, things were totally different about female sculptures. In ancient Greece, people usually connect female nudity with sex, which was unacceptable in tradition Greek culture, especially when it involved into religious cult. Before the creation of Aphrodite of Knidos of Praxiteles, all the female statues were partly all fully clothed, and nearly no one tried to show ideal female bodyline through sculptures. Stansbury-O'Donnell believes that this sculpture of Aphrodite was Praxiteles' innovation in Greek art and society. [3] This sculpture challenged the traditional Greek thoughts about female and also started a new era of female sculptures in the art field. Ironically, although people in Kos it is the nude version that been copied and preserved until today. To some extent, Praxiteles' Aphrodite forced ancient Greek people to think about female social status and urged the improvement of female social status in ancient Greece.

\subsection{Livia.}

Turning to ancient Rome, situation of female was the same as ancient Greece. According to Steven L. Tuck in A History of Roman Art, women were barred by public office while men could celebrate their contribution to the state. [5] However, the appearance of Livia changed this unequal situation between male and female in ancient Roman art.

Livia, the empress of Roman Empire, the wife of Augustus, her statues were "the earliest imperial granted public statues.” (Steven L. Tuck, A History of Roman Art, p165). [5]

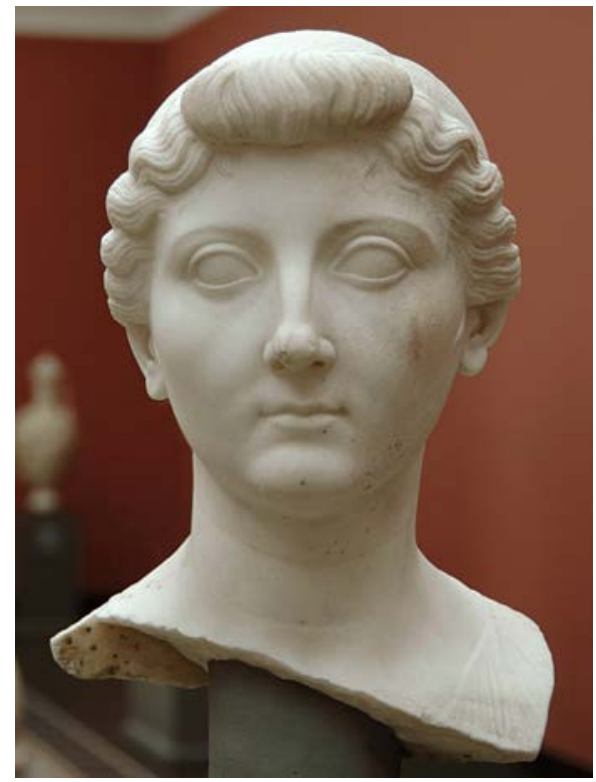

Figure 3 Sosnowska, S. Portrait of Livia.

Digital image. 2008.

Accessed May 22, 2017. http://ancientrome.ru/art/artworken/img.htm?id=2229.

Portrait of Livia, a head portrait that made around the 1st century AD and found in Arsinoe, is a representation of Livia's statues. This statue is made by marble. Her eyes are big and her mouth is closing tightly. Her hairstyle is symmetrical and all of her hair are banded after her head with curly line curved around her cheek.

Different from most of female statues in ancient Greece, Livia's statues are companied with obvious imperial ideology because Roman empress is a part of her identity, perhaps is the most significant part. Tuck points out that "the iconography of imperial women had to be created from nothing and its form established to serve the needs of the dynasty."[5] In this portrait, we cannot find any obvious individual features that about Livia or show her characteristics. In Portraits of Livia: Imaging the Imperial Woman in Augustan Rome, author Elizabeth Bartman also indicates that Livia's portraits were obvious imperial ideological, just like other Augustan art[1]. Her 
portraits could be seen as a female version of Augustus' portraits. The facial features, especially the mouth, and curly hair are very similar between the statues of Augustus and Livia.

Although Livia's statues and her identity were only recognized as a part of Roman Empire and a symbol of imperial ideology, her statues emblemed the increase of female statues as the social status of female improved in this time period. In addition to royal females, there were a few of statues that made for ordinary women in Julio-Claudian dynasty. Rather than young and beautiful girls, there statues are of old women who had wrinkle on their skin. The shift from idealized female body to imperfect female features reflected the shift of public attitudes toward female in JulioClaudian dynasty. Ordinary female could be seen as art. Idealization was not the only criteria of art, imperfect statues with "reality" became a popular trend.

\subsection{The Market Woman.}

This statue of an old woman was made in 1st -century Rome according to Metropolitan Museum of Art. The material of this statue is Pentelic marble, and its dimension is $125.98 \mathrm{~cm}$ height, which is a life-size statue.

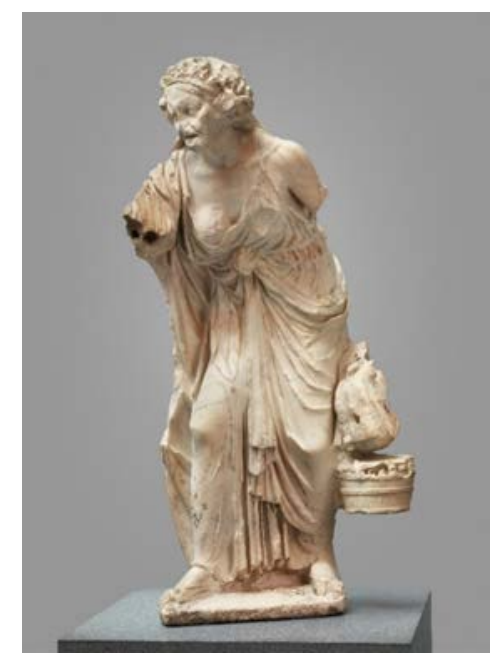

Figure 4 Marble statue of an old woman

Digital image. Marble statue of an old woman. Accessed May 22, 2017. http://www.metmuseum. org/art/collection/search/248132.

This is a statue of an old woman who is hanging a basket in her left hand. She is standing with features of an old woman. On her face, viewers can see the traces of wrinkle. Her eyes and mouth are droop which is a natural and real feature of old people since skin always become slack along with the growth of age. Secondly, she is standing with humpback which indicates her body condition was not young and healthy anymore.

The marble of this statue was not polished as well as the Nike or the head portrait of Livia. Despite of the smash of the open air and the pass of long history, the rough surface might indicate the change of sculpture style in Julio-Claudian period.

She is leaning to her right side while a basket on her left hand. Though viewers cannot see the content inside the basket, we can feel the weight of this basket according to her position. This composition creates a balance of this statue

Comparing to previous examples, this is an ordinary woman who had no connection with religion or royal family. The shown up this type of subject matter indicated an improvement of female social status in ancient Rome. The subject matter was not limited to female who had special identities anymore, even ordinary female could be made into statues, became a part of ancient Roman art.

Idealized body shape and proportion which played important roles in Classical period was ignored on this statue and also in this period. On this statue, viewer cannot find the beautifulness that appeared on the statue of Nike. This old woman had no idealized body shape or smooth skin. She is just an ordinary old woman who lived in ancient Rome. 
The change of social context had huge impact on artworks. Through the changes of female statues in ancient Greece and Rome, the changes of social attitudes towards female reflected on them with the aesthetics about human bodies changed. From the limitation on divine to ordinary female, the widen of subject matter indicated the improvement of female social status in ancient Greece and Rome. The changes of social structure also turned artists and viewers from goddess to imperial rulers.

Besides, there were changes of aesthetics about human bodies in this period. From the rigid body proportion to idealization, and then, to real female bodies, the society had more and more tolerance about "imperfect" female bodies, which, to some extent, suggested the tolerance of female in ancient Greece and Roman society.

\section{Summary}

Inequality between male and female has a long history, sculptors in ancient Greece and Rome use their works to record and reflect a part of this history. I have to admit that these works cannot show the truth of the past since artists must added their own interpretation into their works, but through analyzing these female statues through their hairstyle, clothes and poses, we can get a general thought about the changes of lives and situation that women experienced in ancient Greece and Rome.

Comparing to ancient Chinese statues that made in Han dynasty, ancient Greco-Roman female statues emphasized more on realities and details of body shape, clothing, and hair style, especially in the later period in ancient Roman imperial statues. In Chinese art, the sense behind the work was more important than the form and the style, however, in ancient Greco-Roman art, taking these female statues as examples, the work itself played a more important role. All the development of female statues in this time period indicated one thing that artists paid more and more attention to the details on statues.

\section{References}

[1]. Bartman, Elizabeth. Portraits of Livia: Imaging the Imperial Woman in Augustan Rome. Cambridge, U.K.: Cambridge UP, 1999. Print

[2]. Dillon, Sheila. The female portrait statue in the Greek world. New York: Cambridge University Press, 2010

[3]. Stansbury-O'Donnell, Mark D. A History of Greek Art. Chichester: John Wiley \& Sons, 2015.

[4]. Stewart, Andrew F. Art, Desire, and the Body in Ancient Greece. Cambridge: Cambridge UP, 1997. Print.

[5]. Tuck, Steven L. A History of Roman Art. Chichester: John Wiley \& Sons, 2015. 